\title{
Os nomes da violência contra as mulheres: das narrativas no jornalismo ${ }^{1}$
}

\section{The names of the violence against women: storytelling in journalism}

Mayra Rodrigues Gomes ${ }^{2}$ realizada com bolsa de produtividade em pesquisa concedida pelo CNPq. 


\section{Resumo}

O presente artigo está inserido num conjunto de estudos e averiguações sobre o jornalismo informativo que temos desenvolvido com o intuito de apreender seu estatuto e a natureza dos discursos que ele mobiliza. A proposta de pesquisa foi motivada, no ano de sua apresentação em 2018, pelos altos índices de violência no Brasil. A pesquisa procura captar o espírito das narrativas jornalísticas nos relatos de casos de violência contra as mulheres, entender como o jornalismo está descrevendo esses casos de violência (se de forma a reforçar ou neutralizar estereótipos de natureza negativa) e apreender, em visão panorâmica, a situação da violência contra as mulheres, enquanto apresentada pela produção jornalística.

\section{Palavras-chave}

Jornalismo, violência, mulheres, narrativa, discurso.

\section{Abstract}

This article is part of a set of studies and investigations about journalism developed in order to understand its status and the nature of its discourses. The research was motivated, in the year of 2018, by the high rates of violence in Brazil. The research seeks to capture the spirit of journalistic narratives in the reports of cases of violence against women; to understand how journalism is describing these cases of violence (if in a way to reinforce or neutralize stereotypes of a negative nature); and apprehend, in a panoramic view, the situation of violence against women, as presented by journalistic production.

\section{Keywords}

Journalism, violence, women, narrative, discourse. 


\section{Uma pesquisa e seus aportes}

O presente artigo está inserido num conjunto de estudos e averiguações sobre o jornalismo informativo que temos desenvolvido com o intuito de apreender seu estatuto e a natureza dos discursos que ele mobiliza. A proposta de pesquisa foi motivada, no ano de sua apresentação, em 2018, pelos altos índices de violência no Brasil. No geral, o país foi apontado como o $16^{\circ}$ mais violento do planeta. A taxa nacional era de 25,2 assassinatos a cada 100 mil habitantes, enquanto a média mundial era de 6,2 por 100 mil, dados do Escritório das Nações Unidas sobre Drogas e Crime (UNODC) ${ }^{3}$. O Atlas da Violência 2017, trabalho do Instituto de Pesquisa Econômica Aplicada (Ipea) e do Fórum Brasileiro de Segurança Pública, apresenta os detalhes desses estudos. A pesquisa procura captar o espírito das narrativas jornalísticas nos relatos de casos de violência contra as mulheres, entender como o jornalismo está descrevendo esses casos de violência (se de forma a reforçar ou neutralizar estereótipos de natureza negativa) e apreender, em visão panorâmica, a situação da violência contra as mulheres apresentada pela produção jornalística.

Tendo o jornalismo como foco, para efeitos de viabilidade, houve necessidade de circunscrever esse campo. Nessa redução, o espaço de investigação foi determinado pela maior tiragem, fato que resultou na escolha do jornal Folha de S.Paulo. Tal critério garante grande número de acessos/leitores, assegurando um alcance mais vasto da palavra enunciada pelo veículo, de modo que se tornar referência para muitas interpretações, até mesmo para as escolhas de outros veículos, se considerarmos pertinente a regra do julgamento e balizamento pelos pares, colocada por Pierre Bourdieu (1997, p. 107-108).

Isto posto, há grande probabilidade de que os modos com os quais a Folha de S. Paulo constrói uma matéria reverbere em outros jornais e, pelos mesmos motivos, também reflita os discursos que circulam em nossa cultura, em particular aqueles que norteiam seus leitores. Seguem algumas considerações sobre o universo 
teórico/metodológico que conduz o presente artigo e a pesquisa de que ele brota. Já que investigamos os modos narrativos do jornalismo, nossas explorações devem partir dos elementos constitutivos de suas matérias, a saber, as palavras e as articulações com que elas animam as narrativas.

Ora, entre as palavras e as coisas, há discursos (FOUCAULT, 1995; 1996), as bases de uma cultura, que as abriga e permite sua enunciação. É nas observações de Charaudeau que encontramos a perfeita definição para tal engendramento: "O discurso circulante é uma soma empírica de enunciados com visada definicional sobre o que são os seres, as ações, os acontecimentos, suas características, seus comportamentos e os julgamentos a eles ligados" (CHARAUDEAU, 2006, p. 118). Os discursos que circulam em dada cultura em dado momento, muitas vezes até contraditórios, constituem o panorama em que as compreensões de mundo se atualizam, portanto, o contexto em que alguma coisa, material ou imaterial, alcança seu sentido e, sobretudo, em que as palavras podem encontrar seu encaixe e significação.

Assim, uma palavra per se não basta para a condução de nossas análises e, quando propusemos, na presente pesquisa, um rastreamento por palavras, para com elas chegar a achados sobre a posição do jornalismo e o estatuto das representações sociais das mulheres, nós o fizemos com plena ciência dessa condição. No entanto, também levamos em conta a concepção de Dominique Maingueneau $(1993 ;$ 2008) segundo a qual uma simples palavra, se não pode pesar, para análise de discurso, como unidade suficiente, do ponto de vista da cristalização semântica de um discurso ela tem inequívoco valor significante.

\footnotetext{
Mas seria errado pensar que, em um discurso, as palavras não são empregadas a não ser em razão de suas virtualidades de sentido em língua. Porque, além de seu estrito valor semântico, as unidades lexicais tendem a adquirir o estatuto de signos de pertencimento. Entre vários termos a priori equivalentes, os enunciadores serão levados a utilizar aqueles que marcam sua posição no campo discursivo. (MAINGUENEAU, 2008, p. 81)
}

Por isso, enfatizamos a amplidão de significados, culturalmente enraizados, que compõem os campos em torno das palavras-chave de nossa escolha: violência, 
agressão, assédio, estupro, assassinato, feminicídio, mulher, mulheres. Lembremos o que cada uma delas traz, em forma subentendida, de fatos e condições sociais. Estamos, pois, em nossas ponderações sobre os campos discursivos obtidos nesta pesquisa sempre no cruzamento entre as palavras e os discursos. Portanto, nos situamos no âmbito de significações implícitas, dos pressupostos e subentendidos, bem delineados por Ducrot, pois, para ele, os implícitos visam "[...] a necessidade de se dizerem certas coisas e de se poder fazer como se não as tivesse dito; de dizê-lo, mas de tal forma que se possa recusar a responsabilidade de tê-las dito" (DUCROT, 1977, p. 13).

Por outro lado, ainda numa perspectiva de implicatura, preservamos a noção de que o silêncio remete a significações implícitas. Por deixar de informar ou elucidar questões, ele reforça, consequentemente, o lado mostrado e a rejeição/ apagamento dos fatos silenciados. São as observações de Eni Orlandi que nos guiam nesse entremeio: "Há um modo de estar em silêncio que corresponde a um modo de estar no sentido e, de certa maneira, as próprias palavras transpiram silêncio" (ORLANDI, 2007, p. 11). Permanecemos no registro do que a autora aponta como silêncio constitutivo, que remete ao fato de que um dito, necessariamente, faz apagamento de possíveis ditos não realizados. Esse silêncio deve ser pensado a partir do que ele evoca, ou convoca, uma vez que não deixa marcas específicas no texto, não deixa palavras documentais.

Finalmente, numa pesquisa que procura ver como o jornalismo fala sobre a violência contra as mulheres, e quais discursos ele mobiliza nesse falar, temos que nos rodear por pensadores que legaram investigações em torno de identidade social. Compreendendo que "as identidades são, pois, pontos de apego temporário às posições-de-sujeito que as práticas discursivas constroem para nós" (HALL, 2000, p. 112), complementamos essa afirmação com a de Charaudeau sobre discursos e imaginário: "Os imaginários sociodiscursivos circulam, portanto, em um espaço de interdiscursividade. Eles dão testemunho das identidades coletivas, da percepção que os indivíduos e os grupos têm dos acontecimentos, dos julgamentos que fazem de suas atividades sociais" (CHARAUDEAU, 2008, 
p. 207). E, com o conceito de imaginário sociodiscursivo, tentamos penetrar as concepções sobre as mulheres que emergem do corpus da pesquisa.

\section{Um corpus e seu desenho}

O conjunto do projeto considerou a captação de matérias jornalísticas a partir do jornal Folha de S.Paulo por dois anos, 2019 e 2020 . Essa captação teve início na semana de 8 de março de 2019, com as manifestações em torno do Dia Internacional da Mulher, e sua finalização na semana seguinte ao 8 de março de 2020. As matérias jornalísticas foram obtidas por rastreamento, através de busca no site do jornal, com a combinatória das seguintes palavras-chave: violência, agressão, assédio, estupro, assassinato, feminicídio, mulher, mulheres.

A combinatória foi necessária porque o universo em que essas palavras aparecem é muito amplo e, com muita frequência, sem relação alguma com a temática da violência contra as mulheres. Por outro lado, só a leitura passo a passo de cada matéria jornalística levantada pôde assegurar o conjunto relevante ao tema. Com essa leitura, muitas matérias, pelo distanciamento do tema de pesquisa, foram excluídas. Por exemplo, a palavra violência aparece com muita frequência, no entanto, sem conexão com o universo feminino.

Após esses primeiros passos na constituição do corpus, prosseguimos criando algumas coordenadas que nos facilitassem as análises desse material que totalizou 233 matérias. Procuramos construir, a partir dos vieses que cada matéria sobre violência contra as mulheres assumiu, categorias temáticas (portanto, subtemas do tema central "violência contra as mulheres"), a saber, blocos que compreendem os relatos jornalísticos captados. Esse último procedimento, além de metodologicamente auxiliar na abordagem do corpus, é também uma estratégia mestra para a obtenção de uma visão geral do que circula ou não, e da importância cultural atribuída a cada subtema, assinalada pela maior ou menor incidência de matérias. Ao mesmo tempo, com o número dos relatos sobre ocorrências, podemos ter uma ideia, uma pequena amostra da relevância da temática para o próprio jornalismo. 
Enfatizamos o fato de que as chamadas ou títulos das matérias muitas vezes nos fazem pensar em um subtema, mas nem sempre se desenvolvem no espírito anunciado. Esse é o caso de matéria cuja chamada traz a porcentagem de algum levantamento, mas se desdobra na descrição de casos ou de manifestações públicas. Ainda ressaltamos que, como capturamos on-line as emissões do jornal, muitas vezes temos uma duplicidade, pois ao longo do dia a versão digital estende matérias do impresso, acrescentando pequenos dados de forma a configurar uma nova matéria. O teor das quatro categorias elaboradas será descrito a seguir.

\section{Ações em prol das mulheres, embates, manifestações públicas}

Sob essa rubrica arrolamos qualquer iniciativa que possa representar avanço no respeito às mulheres, seja ele na forma de leis, de penalidades a infratores, de espaços de acolhimento para as vítimas, de estímulo à mudança de costumes, seja por iniciativa do estado ou de entidades privadas. Ainda foram listados nessa categoria os confrontos de posições/opiniões, assim como passeatas, shows e discursos que alertam tanto para circunstâncias de prejuízo quanto para vitórias obtidas na defesa de direitos das mulheres.

\section{Casos}

Estão sob esse nome elencadas as ocorrências de agressão ou morte, com a peculiaridade de que muitas vezes são evocadas infrações passadas, cujas disputas e meandros se estendem, em continuidade, até os dias de hoje.

\section{Condição feminina: panoramas, ponderações}

Procuramos encaixar aqui o relato de condições sociais que apontam para a perpetuação de práticas em que as mulheres se veem inferiorizadas ou perseguidas, algumas remontando a tempos imemoriais. Também encaixamos as matérias que trazem reflexões sobre a condição feminina, num tom exploratório ou teórico/conceitual, sobre os papéis sociais atribuídos às mulheres, junto a medidas desejáveis para que as mulheres possam ser respeitadas. 


\section{Dados/porcentagens}

Finalmente, isolamos num bloco as matérias que trazem levantamentos sobre a situação da violência contra as mulheres em termos do número de ocorrências de feminicídio, de agressões, de exclusão etc. As matérias com esse contorno abrangem situações nacionais, mas também internacionais.

Num retrato por duplas de meses, para efeito de síntese, elaboramos o Quadro 1, com as chamadas de cada matéria. Em alguns casos, também trouxemos o subtítulo porque trazia o tom do relato.

Quadro 1: Matérias Folha de S.Paulo (março/abril 2019)

\begin{tabular}{|c|c|}
\hline \multicolumn{2}{|r|}{ Março/abril 2019} \\
\hline \multicolumn{2}{|r|}{ Ações em prol das mulheres, embates, manifestações públicas } \\
\hline 08/03/2019 & Condenado na Lei Maria da Penha não poderá ter cargo comissionado no RJ \\
\hline $08 / 03 / 2019$ & Argentina aumenta cota de mulheres no Congresso para $50 \%$ \\
\hline $08 / 03 / 2019$ & Seleção feminina dos EUA processa federação por discriminação de gênero \\
\hline $08 / 03 / 2019$ & $\begin{array}{l}\text { Comandante da Guarda de SP deixa cargo um ano após revelada suspeita de desvios. } \\
\text { O prefeito Bruno Covas nomeou uma mulher para o cargo, aproveitando efeméride do Dia } \\
\text { Internacional da Mulher }\end{array}$ \\
\hline $08 / 03 / 2019$ & São Paulo tem mais quatro delegacias da mulher abertas $24 \mathrm{~h}$ a partir desta sexta \\
\hline $08 / 03 / 2019$ & No Brasil, cota parlamentar para mulheres perpetuaria poder masculino \\
\hline $08 / 03 / 2019$ & $\begin{array}{c}\text { Bolsonaro diz que cada uma das duas ministras vale por dez homens Em discurso no Dia da } \\
\text { Mulher, presidente cita Bíblia e afirma que 'mulher sábia edifica o lar' }\end{array}$ \\
\hline $08 / 03 / 2019$ & Marcha das mulheres em SP é marcada por críticas a Bolsonaro e homenagens a Marielle \\
\hline $12 / 03 / 2019$ & Câmara aprova punição para assédio moral no trabalho \\
\hline $13 / 03 / 2019$ & Na ONU, ministra discursa contra aborto e diz que direito da mulher é prioridade \\
\hline $13 / 03 / 2019$ & Imagem de Marielle se espalha por muros de cidades dentro e fora do país \\
\hline $14 / 03 / 2019$ & Vida e trajetória de Marielle inspiram projetos de jovens negras de favelas \\
\hline $19 / 03 / 2019$ & Por que uma Secretaria da Família? \\
\hline $19 / 03 / 2019$ & Agressores de mulheres não poderão tirar carteira de advogado, diz OAB \\
\hline 20/03/2019 & Barrar agressores de tirar OAB é positivo, dizem especialistas \\
\hline 22/03/2019 & SP terá botão de pânico por meio de aplicativo para mulheres em perigo \\
\hline $25 / 03 / 2019$ & Líder do grupo Pussy Riot vai trazer seu protesto punk ao Brasil com livro e shows \\
\hline $27 / 03 / 2019$ & Câmara aprova divórcio imediato em casos de violência doméstica \\
\hline $11 / 04 / 2019$ & $\begin{array}{l}\text { Médico congolês repara corpo e esperança de vítimas de estupro } \\
\text { Denis Mukwege reabilitou } 1.200 \text { mulheres com projeto que transforma dor em poder; Nobel } \\
\text { da Paz é um dos conferencistas do Fronteiras do Pensamento } 2019\end{array}$ \\
\hline $16 / 04 / 2019$ & $\begin{array}{l}\text { Projeto que permite a policiais conceder medida protetiva a vítima de violência é alvo de críticas. } \\
\text { Texto, que altera Lei Maria da Penha, foi aprovado no Senado e aguarda sanção presidencial }\end{array}$ \\
\hline $19 / 04 / 2019$ & Papa celebra Via Crúcis dedicada a escravas sexuais e prostitutas \\
\hline $21 / 04 / 2019$ & Pussy Riot fala muito e canta pouco em show \\
\hline $24 / 04 / 2019$ & acabar com cota feminina nas eleições \\
\hline
\end{tabular}




\begin{tabular}{|c|c|}
\hline \multicolumn{2}{|r|}{ Março/abril 2019} \\
\hline \multicolumn{2}{|r|}{ Casos } \\
\hline 08/03/2019 & Mulher é queimada viva por namorado e morre \\
\hline 08/03/2019 & Judeus ultraortodoxos atacam mulheres que querem rezar no Muro das Lamentações \\
\hline 09/03/2019 & Mulheres sob ataque Agressões cotidianas seguem como realidade para muitas \\
\hline $12 / 03 / 2019$ & $\begin{array}{l}\text { Veja o que se sabe até agora sobre o assassinato da vereadora Marielle Franco Operação } \\
\text { prendeu na manhã desta terça-feira (12) dois suspeitos de participarem do crime }\end{array}$ \\
\hline $21 / 03 / 2019$ & STJ acolhe recurso e João de Deus será transferido para hospital de Goiânia \\
\hline $24 / 03 / 2019$ & Mulher acusa João de Deus de estupro e tentativa de homicídio \\
\hline $26 / 03 / 2019$ & $\begin{array}{c}\text { Equipe de revista feminina do Vaticano se demite em protesto contra editor } \\
\text { Em carta ao papa, Women Church World se diz 'reduzida ao silêncio' após reportagens sobre } \\
\text { abusos de freiras }\end{array}$ \\
\hline $27 / 03 / 2019$ & Guru Deva Nishok é investigado por abuso sexual \\
\hline 29/03/2019 & Lei que veta prisão para gestantes e mães de crianças é descumprida no Rio \\
\hline 29/03/2019 & Polícia de MG pede prisão de tatuador acusado de abusar de clientes \\
\hline 29/03/2019 & Baterista é condenado a 27 anos de prisão por morte de mulher a marteladas \\
\hline $31 / 03 / 2019$ & Remédio usado em aborto legal e casos de hemorragia rareia no SUS \\
\hline $31 / 03 / 2019$ & Tatuador acusado de abuso sexual é preso na região metropolitana de $\mathrm{BH}$ \\
\hline 03/04/2019 & Mulher é morta asfixiada com coleira de cão por namorado em MS \\
\hline 29/04/2019 & Mulheres de Moçambique tiveram que trocar sexo por comida após ciclone, diz ONG \\
\hline \multicolumn{2}{|r|}{ Condição feminina: panoramas, ponderações } \\
\hline 08/03/2019 & Mulher em cargo de chefia chega a ganhar um terço do salário de um homem \\
\hline $08 / 03 / 2019$ & Com apenas presidentes homens, Bolsa promove evento sobre gênero \\
\hline 08/03/2019 & Futuro do feminismo depende de reinvenção de masculinidade, afirma autora \\
\hline 09/03/2019 & Obra aponta dano a mulheres gerados por dados enviesados \\
\hline 09/03/2019 & Mulheres são maioria entre prejudicados pela reforma da Previdência \\
\hline $10 / 03 / 2019$ & Após 70 anos, Simone de Beauvoir ainda mostra caminho da liberdade feminina \\
\hline $12 / 03 / 2019$ & Lei faz com que meninas estupradas fiquem sem perícia no Rio por falta de médicas \\
\hline 03/04/2019 & Um tributo contra as mulheres. Estudos apontam relação entre maternidade e queda de salário \\
\hline \multicolumn{2}{|r|}{ Dados/porcentagens } \\
\hline 08/03/2019 & $71 \%$ dos feminicídios e das tentativas têm parceiro como suspeito \\
\hline 23/03/2019 & Registros de crimes sexuais em coletivos de SP crescem $265 \%$ em 11 anos \\
\hline $14 / 04 / 2019$ & Para 9 entre 10 , violência contra mulheres aumentou, diz Datafolha \\
\hline $14 / 04 / 2019$ & Feminismo é mais bem avaliado entre homens que entre mulheres, diz Datafolha \\
\hline $30 / 04 / 2019$ & No Rio, uma mulher foi morta a cada cinco dias por ser mulher em 2018 \\
\hline
\end{tabular}

Quadro 2: Matérias Folha de S.Paulo (maio/junho 2019)

\begin{tabular}{|c|c|}
\hline \multicolumn{2}{|c|}{ Maio/junho 2019} \\
\hline \multicolumn{2}{|c|}{ Ações em prol das mulheres, embates, manifestações públicas } \\
\hline $02 / 05 / 2019$ & Séries refletem ascensão das mulheres depois do \#MeToo \\
\hline $07 / 05 / 2019$ & Ministério da Saúde veta uso do termo 'violência obstétrica' \\
\hline $10 / 05 / 2019$ & Ministério da Saúde mantém decisão de não usar termo violência obstétrica, diz secretário \\
\hline $11 / 05 / 2019$ & Com nome de Elis Regina, gremistas criam torcida feminista \\
\hline $12 / 05 / 2019$ & Mães no sistema prisional Prisão preventiva pode ser substituída por domiciliar \\
\hline $18 / 05 / 2019$ & Vítimas de abuso sexual estão cientes de que são vítimas de fato, diz Joanna Maranhão \\
\hline
\end{tabular}




\begin{tabular}{|c|c|}
\hline \multicolumn{2}{|r|}{ Maio/junho 2019} \\
\hline $18 / 05 / 2019$ & Crime contra a infância prolifera no ritmo acelerado das novas plataformas \\
\hline $24 / 05 / 2019$ & Projetos de lei buscam criminalizar o 'stalking' no Brasil \\
\hline \multicolumn{2}{|r|}{ Ações em prol das mulheres, embates, manifestações públicas } \\
\hline $27 / 05 / 2019$ & Bancada feminina fará emendas à reforma da Previdência \\
\hline $28 / 05 / 2019$ & É pela vida das mulheres. Violência obstétrica precisa ser debatida no país \\
\hline 29/05/2019 & STF derruba trecho da reforma trabalhista e proíbe grávida em local insalubre \\
\hline $08 / 06 / 2019$ & Projeto ensina liderança para meninas na periferia de São Paulo \\
\hline $11 / 06 / 2019$ & Projeto quer cesárea sem indicação clínica a gestantes do SUS \\
\hline \multicolumn{2}{|r|}{ Casos } \\
\hline $13 / 05 / 2019$ & Promotoria sueca reabre investigação contra Assange por suspeita de abuso sexual \\
\hline $13 / 05 / 2019$ & Cannes tem abaixo-assinado contra Alain Delon, que disse ter estapeado mulheres \\
\hline $14 / 05 / 2019$ & Enfermeira tem recorde inicialmente negado por correr maratona de calça \\
\hline $16 / 05 / 2019$ & Gafisa é condenada a pagar $\mathrm{R} \$ 400$ mil a ex-funcionária por ofensas sexistas \\
\hline $18 / 05 / 2019$ & Você não entende, depois nega e, por fim, se desespera, diz mãe de vítima de abuso sexual \\
\hline $18 / 05 / 2019$ & Cresce tipo de crime em que vítima é forçada a produzir imagens sexuais \\
\hline $18 / 05 / 2019$ & Turismo sexual é controlado por máfias e fica à margem de estatísticas \\
\hline $21 / 05 / 2019$ & Tema de série, mulher que cortou pênis de marido diz que ele ainda a persegue \\
\hline $23 / 05 / 2019$ & Homem assassina a ex, entra em igreja evangélica e mata 3 em Minas \\
\hline $26 / 05 / 2019$ & Polícia Federal conclui que houve tentativa de atrapalhar investigações do caso Marielle \\
\hline $31 / 05 / 2019$ & \# MeToo afasta maestros renomados e abala alicerces de orquestras \\
\hline $01 / 06 / 2019$ & PM que mentiu em investigação da morte de Marielle é preso em operação no Rio \\
\hline $02 / 06 / 2019$ & Brasileira acusa Neymar de estupro em Paris \\
\hline 02/06/2019 & Em vídeo, Neymar nega estupro e expõe troca de mensagens \\
\hline 02/06/2019 & Polícia investiga Neymar por divulgação de fotos íntimas \\
\hline $02 / 06 / 2019$ & Jogadores da seleção defendem Neymar após acusação de estupro \\
\hline 03/06/2019 & Ex-advogado da mulher que acusa Neymar afirma que ela relatou agressão, não estupro \\
\hline $03 / 06 / 2019$ & O que se sabe a respeito das investigações sobre Neymar \\
\hline 04/06/2019 & Neymar é cobrado por patrocinadores após acusação de abuso sexual \\
\hline 04/06/2019 & STJ determina que João de Deus, no hospital desde março, volte à prisão \\
\hline 04/06/2019 & Neymar expôs meu filho, diz ex-marido de mulher que acusa jogador \\
\hline 04/06/2019 & Polícia aceita adiar depoimento de Neymar no Rio \\
\hline $05 / 06 / 2019$ & Globo afasta Mauro Naves, que passou contato de Neymar pai a advogado \\
\hline 05/06/2019 & Mulher diz que Neymar ignorou apelo e forçou ato sexual sem camisinha \\
\hline 06/06/2019 & Advogada feminista entra para defesa de Neymar e diz que acusação de estupro é falsa \\
\hline $06 / 06 / 2019$ & Neymar ouve apoio da torcida e deixa campo lesionado em Brasília \\
\hline $08 / 06 / 2019$ & Mulher que acusa Neymar não citou camisinha em 10 depoimento \\
\hline $10 / 06 / 2019$ & Advogado de mulher que acusa Neymar de estupro deixa o caso \\
\hline $10 / 06 / 2019$ & Advogado diz que deixará o caso se Najila não entregar celular \\
\hline $11 / 06 / 2019$ & Vigiado por mais de 50 policiais, Neymar deverá depor na quinta \\
\hline $11 / 06 / 2019$ & Game Fifa tira atletas da capa após acusações contra Ronaldo e Neymar \\
\hline $11 / 06 / 2019$ & Neymar repete o que sempre fez e deixa defesa de acusação para o pai \\
\hline $13 / 06 / 2019$ & $\begin{array}{c}\text { Por ordem judicial, Bolsonaro pede desculpas à deputada Maria do Rosário } \\
\text { Presidente foi obrigado a postar mensagem por ter dito que petista 'não merecia ser estuprada' }\end{array}$ \\
\hline $13 / 06 / 2019$ & A verdade aparece cedo ou tarde, diz Neymar após depor em São Paulo \\
\hline $13 / 06 / 2019$ & $\begin{array}{l}\text { Capa de jornal francês sobre Copa feminina gera acusação de misoginia } \\
\text { Publicação satírica Charlie Hebdo tem desenho de vulva com uma bola de futebol }\end{array}$ \\
\hline $18 / 06 / 2019$ & Advogado de Najila diz que celular dela sumiu após depoimento \\
\hline
\end{tabular}




\begin{tabular}{|c|c|}
\hline \multicolumn{2}{|r|}{ Maio/junho 2019} \\
\hline \multicolumn{2}{|r|}{ Casos } \\
\hline $20 / 06 / 2019$ & Sem celular e sem vídeo, advogado pede acareação entre Najila e Neymar \\
\hline $20 / 06 / 2019$ & De Neymar a 'Shallow Now', músicas usam polêmicas para ter sucesso na internet \\
\hline 24/06/2019 & 'Ela não é meu tipo', diz Trump sobre mulher que o acusa de estupro \\
\hline $25 / 06 / 2019$ & Após acusações de discriminação de gênero, Petrobras revisa regras de pagamento de bônus \\
\hline \multicolumn{2}{|r|}{ Condição feminina: panoramas, ponderações } \\
\hline $06 / 05 / 2019$ & Homofobia de hoje é resultado direto dos erros da esquerda, diz Camille Paglia \\
\hline 09/05/2019 & Médicas estão a caminho de serem maioria, mas ganham menos do que médicos \\
\hline $18 / 05 / 2019$ & Série mostra como sociedade dá mais valor ao pênis que à vida da mulher \\
\hline $30 / 05 / 2019$ & Juiz eleitoral compara mulheres que preenchem cota em eleição a 'aleijados' \\
\hline 02/06/2019 & Testes de drogas cardiológicas são feitos com só $1 / 3$ de mulheres \\
\hline 03/06/2019 & Apesar de recorde de congressistas, EUA não priorizam políticas públicas para mulheres \\
\hline 06/06/2019 & Pioneira no futebol, árbitra bateu de frente com Havelange para apitar \\
\hline 06/06/2019 & Proibido no Brasil, futebol feminino já foi até atração de circo \\
\hline $07 / 06 / 2019$ & Caso Neymar mostra amadurecimento do feminismo de hashtag \\
\hline $18 / 06 / 2019$ & Por que as mulheres, e não os homens, são julgadas pela casa bagunçada \\
\hline $19 / 06 / 2019$ & Aborto legal é negado em $57 \%$ dos hospitais que governo indica para procedimento \\
\hline $20 / 06 / 2019$ & $\begin{array}{c}\text { Najila, Neymar e os comentários. Muitos nem cogitam a possibilidade de que as mulheres } \\
\text { tenham desejos sexuais }\end{array}$ \\
\hline $22 / 06 / 2019$ & Promotoria pede que médico envolvido em trote machista pague $\mathrm{R} \$ 39 \mathrm{mil}$ \\
\hline 23/06/2019 & Palavra 'bitch' faz advogado abrir guerra semântica em tribunal no Rio \\
\hline 24/06/2019 & Holiday propõe restrições ao aborto em SP e internação psiquiátrica para grávidas \\
\hline $28 / 06 / 2019$ & Estado de São Paulo registra recorde histórico de mortalidade materna \\
\hline \multicolumn{2}{|r|}{ Dados/porcentagens } \\
\hline $25 / 05 / 2019$ & Hollywood prioriza diversidade, mas ainda contrata poucas diretoras \\
\hline $05 / 06 / 2019$ & Morte de mulheres dentro de casa cresce $17 \%$ em cinco anos \\
\hline
\end{tabular}

Fonte: elaborado pela autora.

Quadro 3: Matérias Folha de S.Paulo (julho/agosto 2019)

\begin{tabular}{|l|c|}
\hline & Julho/agosto 2019 \\
\hline & Ações em prol das mulheres, embates, manifestações públicas \\
\hline $03 / 07 / 2019$ & Comissão do Senado aprova inclusão de prevenção à violência contra mulher nas escolas \\
\hline $07 / 07 / 2019$ & $\begin{array}{c}\text { Câmara vê explosão de projetos para combater violência contra mulheres } \\
\text { Em } 5 \text { meses, atual legislatura soma ao menos 145 iniciativas; anterior propôs 50 no primeiro ano }\end{array}$ \\
\hline $23 / 07 / 2019$ & Casas sigilosas blindam mulheres de companheiros violentos \\
\hline $07 / 08 / 2019$ & Moro diz que homens são violentos por se intimidarem com mulheres e é criticado \\
\hline $08 / 08 / 2019$ & Lei Maria da Penha deu frutos, mas falta sensibilizar juízes, mostra estudo do CNJ \\
\hline $10 / 08 / 2019$ & Passe livre a mulheres como medida para evitar estupros gera polêmica na Índia \\
\hline & 'Primeira vez com negão não dói', diz promotor a defensora em júri na BA \\
\hline $05 / 07 / 2019$ & Prefeito médico do CE suspeito de abuso sexual é afastado do cargo \\
\hline $15 / 07 / 2019$ & Homem espalha cartazes por SP oferecendo programa sexual com ex-mulher \\
\hline $16 / 07 / 2019$ & Ex-marido é condenado a 15 anos de prisão por decepar as duas mãos da mulher \\
\hline $18 / 07 / 2019$ & Polícia prende médico suspeito de abusar de pacientes no Ceará \\
\hline $19 / 07 / 2019$ & Cristiano Ronaldo não será acusado em caso de agressão sexual nos EUA \\
\hline $23 / 07 / 2019$ &
\end{tabular}




\begin{tabular}{|c|c|}
\hline \multicolumn{2}{|r|}{ Julho/agosto 2019} \\
\hline \multicolumn{2}{|r|}{ Casos } \\
\hline $25 / 07 / 2019$ & Ex-marido diz que Najila relatou agressão e não estupro de Neymar \\
\hline $29 / 07 / 2019$ & Polícia decide não indiciar Neymar em acusação de estupro \\
\hline $30 / 07 / 2019$ & Para delegada, não há provas para incriminar Neymar por estupro \\
\hline $31 / 07 / 2019$ & Pai de Neymar vai à Justiça contra ex-advogado de Najila \\
\hline $05 / 08 / 2019$ & Novo julgamento inocenta homem preso no Ceará durante 5 anos por estupro \\
\hline $06 / 08 / 2019$ & Homem é preso após fingir ser policial federal e enganar mulheres em 4 estados \\
\hline 08/08/2019 & Tribunal absolve acusado de estupro com alegação que vítima estava bêbada \\
\hline $13 / 08 / 2019$ & Tenor Plácido Domingo é acusado de assédio sexual por nove mulheres \\
\hline $13 / 08 / 2019$ & Justiça revoga prisão domiciliar de Abdelmassih após revelação de livro de detento \\
\hline $13 / 08 / 2019$ & Goleiro Bruno tem propostas e pedirá à Justiça para voltar a jogar \\
\hline \multicolumn{2}{|r|}{ Condição feminina: panoramas, ponderações } \\
\hline 02/07/2019 & Mulheres consomem mais games, mas ainda sofrem assédio e hostilidade \\
\hline $10 / 07 / 2019$ & Mulheres enfrentam machismo no caminho para a elite dos eSports \\
\hline $22 / 07 / 2019$ & Médicos de áreas violentas relatam impacto de crimes na saúde \\
\hline $22 / 07 / 2019$ & Mulheres vítimas de violência têm risco 8 vezes maior de morrer, aponta estudo \\
\hline $01 / 08 / 2019$ & Famosas abusadas têm o benefício da dúvida, as imigrantes não, diz finalista do Pulitzer \\
\hline 07/08/2019 & Lei Maria da Penha, 13 anos: direito de viver sem violência \\
\hline $10 / 08 / 2019$ & Estupro na literatura pode reforçar intimidação da mulher, diz escritora \\
\hline $21 / 08 / 2019$ & Violência sexual é como uma metástase, diz vencedor do Nobel \\
\hline $30 / 08 / 2019$ & $\begin{array}{c}\text { Nova geração revê 'masculinidade tóxica'; em estudo, 70\% relatam serem treinados } \\
\text { a 'ser macho' }\end{array}$ \\
\hline \multicolumn{2}{|r|}{ Dados/porcentagens } \\
\hline $03 / 07 / 2019$ & Candidatas recebem mais verba eleitoral após cota, mas partidos descumprem regras \\
\hline
\end{tabular}

Quadro 4: Matérias Folha de S.Paulo (setembro/outubro 2019)

\begin{tabular}{|l|r|}
\hline \multicolumn{3}{|c|}{ Ações em prol das mulheres, embates, manifestações públicas } \\
\hline $08 / 10 / 2019$ & Bolsonaro sanciona projetos que ampliam proteção à mulher em situações de violência \\
\hline $20 / 10 / 2019$ & A vítima decide. Bolsonaro acerta ao vetar projeto mal concebido sobre violência contra a mulher \\
\hline \multicolumn{2}{|c|}{ Casos } \\
\hline $10 / 09 / 2019$ & Najila Trindade é indiciada sob acusação de extorquir Neymar \\
\hline $23 / 09 / 2019$ & Plácido Domingo cancela participação em espetáculo após acusações de assédio \\
\hline $24 / 09 / 2019$ & Robert De Niro é acusado de discriminação de gênero \\
\hline $04 / 10 / 2019$ & Justiça revoga prisão domiciliar de ex-médico Roger Abdelmassih \\
\hline $08 / 10 / 2019$ & Ex-presidente da WeWork é acusado de discriminar funcionária grávida \\
\hline $17 / 10 / 2019$ & Condição feminina: panoramas, ponderações \\
\hline $31 / 10 / 2019$ & Violência política de gênero afasta mulheres da vida pública \\
\hline &
\end{tabular}




\begin{tabular}{|c|c|}
\hline \multicolumn{2}{|c|}{ Cetembro/outubro2019 } \\
\hline \multicolumn{2}{|c|}{ 'Backlash' Partidos não querem dividir fundos com as candidatas } \\
\hline $19 / 09 / 2019$ & O que eles chamam de amor, nós chamamos de trabalho não pago, diz Silvia Federici \\
\hline $14 / 10 / 2019$ & Paulistanos defendem lei dura e direitos de mulheres e negros, diz pesquisa \\
\hline $23 / 10 / 2019$ & Dados/porcentagens \\
\hline \multicolumn{2}{|c|}{ Capão Redondo lidera ranking de violência contra a mulher em São Paulo } \\
\hline $09 / 09 / 2019$ & Lei de importunação sexual completa 1 ano com 3.090 casos em SP \\
\hline $26 / 09 / 2019$ & Registros de estupro em SP têm $2^{\circ}$ pior mês desde 2010 \\
\hline $26 / 10 / 2019$ & Castra 1 caso de agressão a mulher a cada 4 minutos, mostra levantamento \\
\hline
\end{tabular}

Quadro 5: Matérias Folha de S.Paulo (novembro/dezembro 2019).

\begin{tabular}{|c|c|}
\hline \multicolumn{2}{|r|}{ Novembro/dezembro 2019} \\
\hline \multicolumn{2}{|r|}{ Ações em prol das mulheres, embates, manifestações públicas } \\
\hline $01 / 11 / 2019$ & Grupo antiaborto acampa diante de hospital em SP para constranger vítimas de estupro \\
\hline $11 / 11 / 2019$ & Quatro anos após início das obras, Casa da Mulher Brasileira é inaugurada em SP sob protestos \\
\hline \multicolumn{2}{|r|}{ Casos } \\
\hline $11 / 11 / 2019$ & Polanski rejeita acusações de estupro na França e estuda entrar na Justiça \\
\hline $26 / 11 / 2019$ & $\begin{array}{l}\text { Em } 4 \text { dias, } 4 \text { mulheres são mortas por conhecidos em SP } \\
\text { Crimes no interior colaboram para aumento de } 27,3 \% \text { dos feminicídios no estado }\end{array}$ \\
\hline $28 / 11 / 2019$ & Universitária é morta a tiros no recôncavo baiano; ex-namorado é suspeito \\
\hline $30 / 11 / 2019$ & Bastidores de casos de assédio sexual em Hollywood têm ritmo de thriller em livro \\
\hline $11 / 12 / 2019$ & Harvey Weinstein e mulheres que o acusam de assédio chegam a acordo provisório \\
\hline $13 / 12 / 2019$ & ONU denuncia tortura e violência sexual contra manifestantes no Chile \\
\hline $19 / 12 / 2019$ & João de Deus é sentenciado a 19 anos de prisão em regime fechado \\
\hline \multicolumn{2}{|r|}{ Condição feminina: panoramas, ponderações } \\
\hline $09 / 12 / 2019$ & Estupro: um custo intolerável à sociedade \\
\hline 29/12/2019 & Debate sobre armas ignora feminicídios \\
\hline \multicolumn{2}{|r|}{ Dados/porcentagens } \\
\hline $07 / 11 / 2019$ & Educação para a equidade de gênero não é ideologia, mas questão de direitos humanos, diz juiz \\
\hline $04 / 12 / 2019$ & $\begin{array}{c}\text { A cada } 20 \text { minutos, } 1 \text { menina é vítima de estupro no país Levantamento do Fórum Brasileiro } \\
\text { de Segurança Pública mostra que houve } 50.899 \text { registros de crimes contra jovens de até } \\
18 \text { anos em } 2017 \text { e } 2018\end{array}$ \\
\hline
\end{tabular}

Quadro 6: Matérias Folha de S.Paulo (janeiro/fevereiro 2020).

\begin{tabular}{|c|c|}
\hline \multicolumn{2}{|c|}{ Janeiro/fevereiro $\mathbf{2 0 2 0}$} \\
\hline $22 / 01 / 2020$ & Artista italiano transforma mulheres famosas em vítimas de violência \\
\hline $28 / 01 / 2020$ & Bolsonaro e Putin querem criar nações fascistas, diz integrante do Pussy Riot \\
\hline $05 / 02 / 2020$ & Marchinhas, rodas de conversa e 'anjos' buscam combater abuso sexual no Carnaval de SP \\
\hline $17 / 02 / 2020$ & Projeto que obriga reeducação de agressores esbarra em falta de oferta de grupos e regras \\
\hline $18 / 02 / 2020$ & Aplicativos de transporte criam campanhas contra abuso sexual no Carnaval \\
\hline
\end{tabular}




\begin{tabular}{|c|c|}
\hline \multicolumn{2}{|r|}{ Janeiro/fevereiro 2020} \\
\hline \multicolumn{2}{|r|}{ Casos } \\
\hline $06 / 01 / 2020$ & Harvey Weinstein recebe novas acusações de estupro, em Los Angeles \\
\hline $07 / 01 / 2020$ & Polícia apura agressão por homofobia no parque Hopi Hari, em SP \\
\hline $10 / 01 / 2020$ & Gerente de bar é condenado por estuprar e matar com taco de beisebol ativista em SP \\
\hline $15 / 01 / 2020$ & $\begin{array}{l}\text { Charlize Theron e Margot Robbie contam como foi viver vítimas de assédio do todo-poderoso } \\
\text { da Fox News }\end{array}$ \\
\hline $20 / 01 / 2020$ & João de Deus é condenado a 40 anos de prisão em regime fechado \\
\hline $13 / 02 / 2020$ & Livro conta como João de Deus foi de astro de festa com artistas a condenado por assédio sexual \\
\hline $18 / 02 / 2020$ & Polícia investiga motorista que fez insinuação sexual a passageira menor de idade \\
\hline $24 / 02 / 2020$ & Condenado por abuso sexual e estupro, Harvey Weinstein se livra de prisão perpétua \\
\hline $27 / 02 / 2020$ & $\begin{array}{l}\text { Roman Polanski não irá ao César, o Oscar francês, após críticas feministas } \\
\text { O diretor, que é condenado por estupro, lidera as indicações na premiação }\end{array}$ \\
\hline \multicolumn{2}{|r|}{ Condição feminina: panoramas, ponderações } \\
\hline $02 / 01 / 2020$ & Caminho seguro. No combate à violência, não há oposição entre gasto social e reforço policial \\
\hline $10 / 01 / 2020$ & Gestos vazios do governo para as mulheres \\
\hline $16 / 01 / 2020$ & Filho de Woody Allen narra em livro complôs para blindar Harvey Weinstein \\
\hline $07 / 02 / 2020$ & Assédio, estrutura precária e insegurança afastam mulheres de estádios \\
\hline $27 / 02 / 2020$ & Espetáculo narra história de violência doméstica sofrida por Maria da Penha \\
\hline \multicolumn{2}{|r|}{ Dados/porcentagens } \\
\hline $24 / 01 / 2020$ & Homicídios dolosos caem em SP, mas mortes por policiais têm alta \\
\hline $22 / 02 / 2020$ & $\begin{array}{c}\text { Feminicídio cresce no Brasil e explode em alguns estados } \\
\text { Compilação inédita de dados mostra registro de } 1.310 \text { mulheres mortas por violência } \\
\text { doméstica em } 2019\end{array}$ \\
\hline $25 / 02 / 2020$ & $\begin{array}{c}\text { Mais feminicídios Fixação de penas maiores não inibiu esse crime; certeza da punição } \\
\text { importa mais }\end{array}$ \\
\hline
\end{tabular}

Fonte: elaborado pela autora.

Quadro 7: Matérias Folha de S.Paulo (março 2020).

\begin{tabular}{|c|c|}
\hline \multicolumn{2}{|r|}{ Março 2020} \\
\hline \multicolumn{2}{|r|}{ Ações em prol das mulheres, embates, manifestações públicas } \\
\hline $07 / 03 / 2020$ & Mulheres de direita veem 8 de Março sequestrado pela esquerda e celebram com ações próprias \\
\hline $07 / 03 / 2020$ & Manifestações do Dia da Mulher ganham tom de resposta a ato pró-Bolsonaro \\
\hline 08/03/2020 & Mulher, como inúmeras brasileiras. Marielles sobrevivem, apesar de violências e assédios \\
\hline $08 / 03 / 2020$ & Mulheres turbinam protestos com dois dias de ato e greve na América Latina \\
\hline $08 / 03 / 2020$ & Em protestos pelo país, mulheres repudiam Bolsonaro e violência de gênero \\
\hline $08 / 03 / 2020$ & Manifestações ganham fôlego na América Latina no Dia Internacional da Mulher \\
\hline \multicolumn{2}{|r|}{ Casos } \\
\hline $04 / 03 / 2020$ & $\begin{array}{c}\text { Vítimas de violência doméstica, mulheres indígenas tropeçam em distância e idioma } \\
\text { para denunciar }\end{array}$ \\
\hline $10 / 03 / 2020$ & Vítima diz que Testemunhas de Jeová ignoraram queixas sobre abusos sexuais \\
\hline \multicolumn{2}{|r|}{ Condição feminina: panoramas, ponderações } \\
\hline 07/03/2020 & Mulheres relatam pressão no trabalho após gravidez \\
\hline $07 / 03 / 2020$ & Meninas prestes a nascer têm a espera marcada por medo de abuso e barreiras \\
\hline $08 / 03 / 2020$ & Repudiar Polanski não é 'cancelar', mas dar um basta à cultura da hipocrisia \\
\hline $08 / 03 / 2020$ & Se há o que comemorar no Dia da Mulher, o avanço é lento diante de disparidades \\
\hline \multicolumn{2}{|r|}{ Dados/porcentagens } \\
\hline $07 / 03 / 2020$ & No mundo e no Brasil, $90 \%$ têm preconceitos sexistas, diz ONU \\
\hline
\end{tabular}

Fonte: elaborado pela autora. 


\section{Uma visão geral do corpus}

Depois de agruparmos o corpus em torno das categorias criadas, que dele mesmo emergiram, elencamos numericamente as ocorrências para que possamos ter um panorama da cadência dessas mês a mês. Assim, podemos apresentar um quadro geral das ocorrências durante o ano todo, a saber, de 8 de março de 2019 a 8 de março de 2020.

Tabela 1: Ocorrência de categorias analíticas (março 2019/março 2020).

\begin{tabular}{ccccc}
\hline & $\begin{array}{c}\text { Ações em prol das mulheres, } \\
\text { embates, manifestações } \\
\text { públicas }\end{array}$ & Casos & $\begin{array}{c}\text { Condição feminina: } \\
\text { panoramas, ponderações }\end{array}$ & $\begin{array}{c}\text { Dados/ } \\
\text { porcentagens }\end{array}$ \\
\hline Março/2019 & 18 & 13 & 7 & 2 \\
Abril/2019 & 5 & 2 & 3 & 1 \\
Maio/2019 & 10 & 12 & 1 & 4 \\
Junho/2019 & 3 & 29 & 12 & 1 \\
Julho/2019 & 3 & 11 & 4 & 1 \\
Agosto/2019 & 3 & 6 & 5 & 0 \\
Setembro/2019 & 0 & 3 & 4 & 3 \\
Outubro/2019 & 2 & 4 & 2 & 1 \\
Novembro/2019 & 1 & 4 & 0 & 1 \\
Dezembro/2019 & 0 & 3 & 2 & 1 \\
Janeiro/2020 & 2 & 5 & 3 & 1 \\
Fevereiro/2020 & 3 & 4 & 2 & 2 \\
Março/2020 & 6 & 2 & 4 & 1 \\
\hline
\end{tabular}

Fonte: elaborado pela autora.

\section{CATEGORIAS MÊS A MÊS}

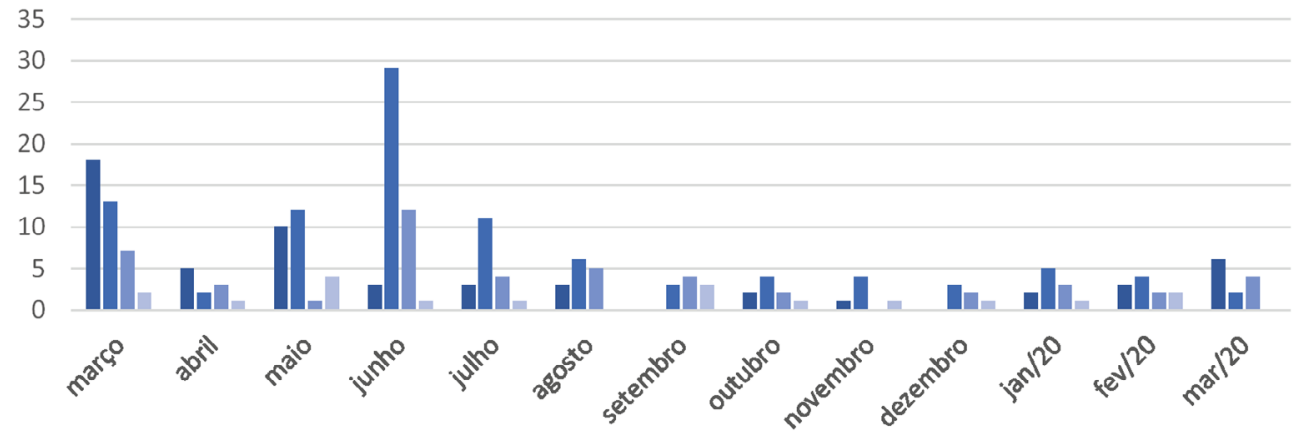

- Ações em prol das mulheres, embates, manifestações públicas

- Casos

— Condição feminina: panoramas, ponderações

Dados/porcentagens

Gráfico 1: Ocorrência de categorias analíticas (mês a mês).

Fonte: elaborado pela autora. 
No conjunto do ano de coleta chegamos ao seguinte quadro: Ações em prol das mulheres, embates, manifestações públicas - 57; Casos - 98; Condição feminina: panorama, ponderações - 50; e Dados/porcentagens - 18.

MARÇO 2019 A MARÇO 2020

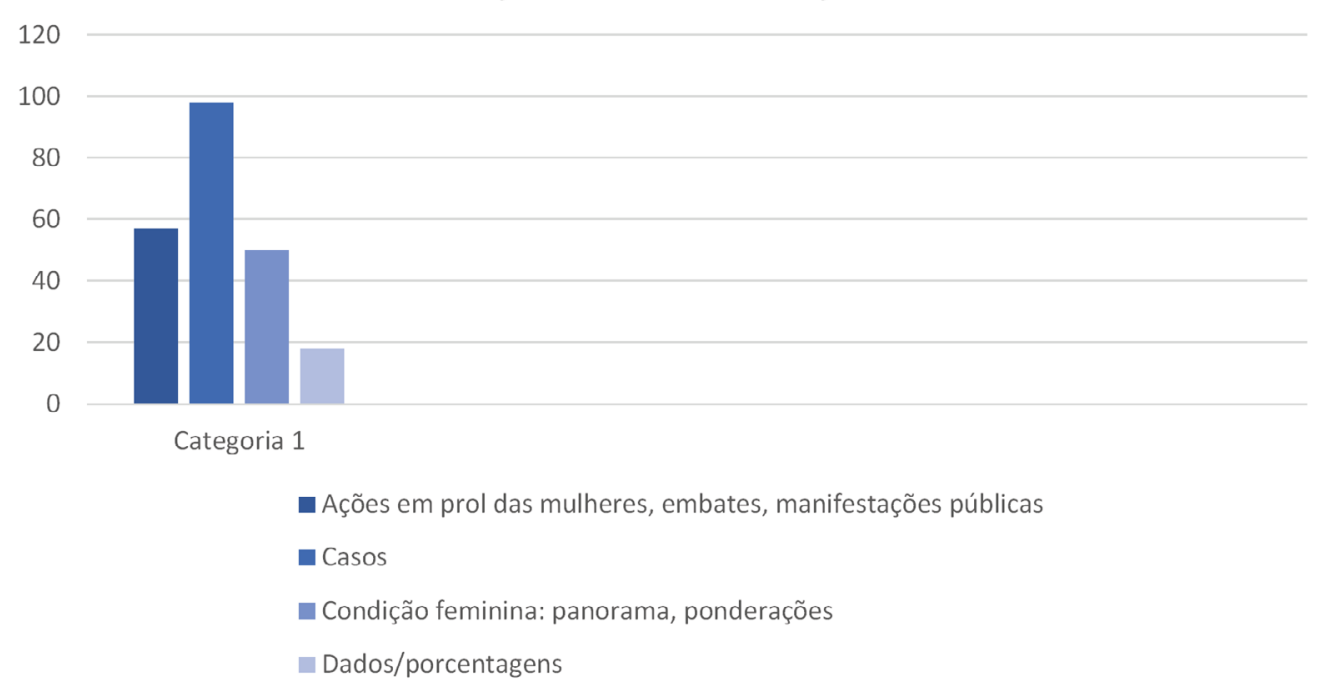

Gráfico 2: Ocorrência de categorias analíticas (totais).

Fonte: elaborado pela autora.

\section{Apontamentos}

Começamos por anotar que, quando propusemos o projeto de pesquisa, não tínhamos a mais remota ideia das condições socioculturais que fariam fundo a todo o período em que a coleta de dados se dispõe.

De um lado, tivemos a crescente polarização das posições políticas, as exacerbadas campanhas realizadas a toque de fake news, as afirmações bombásticas e polêmicas do presidente Bolsonaro, a pandemia que se instalou com a Covid-19, a quarentena mundo afora, o crescente número de mortes, as disputas em torno de ações preventivas (com continuidade nos dias de hoje), ações preventivas sequestradas por posições políticas e, no limite, um quadro social muito diferente do que supúnhamos. Talvez esse quadro bem diferente tenha propiciado a vinda de situações insuspeitadas à tona, que aparecem à revelia nas páginas dos jornais. Passo a passo apresentamos agora nossas análises dos dados a partir das categorias em que estão arrolados. 


\section{Casos}

Como o gráfico das ocorrências anuais nos mostra, a categoria Casos detém o maior percentual de notícias, a maioria delas durante os meses de março, maio, junho e julho. Em março comparecem os casos em continuidade, que já se arrastavam há algum tempo, com seus desdobramentos ou efeitos. Há matérias sobre as investigações do assassinato de Marielle Franco e sobre o julgamento e prisão de João de Deus. Neste último caso, vemos bem o efeito cascata (as vítimas que são estimuladas pelo consenso em torno da culpabilidade do agressor), pois novas acusações ainda surgem. Por exemplo, em 24 de março de 2019, temos "Mulher acusa João de Deus de estupro e tentativa de homicídio".

Não podemos deixar de lado reverberações do movimento MeToo, pois, em 13 de maio 2019, é publicada a matéria "Cannes tem abaixo-assinado contra Alain Delon, que disse ter estapeado mulheres". Ainda no começo do ano, temos as ocorrências de abusos sexuais, agressões e assassinatos que o jornal carrega nas tintas, aos modos de notícias sensacionalistas, sobretudo em termos de chamadas (em 29/3/2019, "Baterista é condenado a 27 anos de prisão por morte de mulher a marteladas"). É nesses delitos que vemos com clareza a circulação de discursos tragicamente tradicionais, através de consolidados imaginários sociodiscursivos sobre as mulheres. Isso porque os agressores frequentemente recorrem a argumentações para seus atos em função de uma "falha" da mulher. Eles mal se pensam infratores, porque suas vítimas fizeram por merecer, simplesmente por serem mulheres que, segundo eles, carregam características precisas: propensas a traição, desobedientes em relação a seus parceiros, sedutoras quando deveriam ser recatadas etc.

Mas também ficam muito claras situações marcantes em nossa cultura, ou talvez em combinação com as características e segmento social dos leitores do jornal. Trata-se do fato de que, apesar das estatísticas revelarem que "ao menos 119 mulheres foram mortas no Brasil em janeiro por causa de seu gênero" (matéria de 8/3/2019), há uma notória sub-representação desses casos nas matérias jornalísticas sob três aspectos: 1) o número de matérias é bem inferior ao número 
de casos; 2) os casos relatados são ocorrências em meio a classe média; não há referências a assassinatos de mulheres em situação de rua, por exemplo; 3) os casos relatados, com exceção do jornalisticamente bem documentado assassinato de Marielle Franco, passam ao largo do assassinato/abuso, estupro etc. de mulheres negras ou afrodescendentes (apesar de que, pelos levantamentos, 68,6\% das vítimas são negras ou pardas); presença dessas mulheres nos jornais está fortemente ligada à notoriedade pública ou posição institucional (como caso de Marielle).

Certamente há um silêncio que alude à discriminação/desimportância de gênero e de classe social. E, por falar em notoriedade, o que faz com que Casos estoure no gráfico de junho, respingando em julho e agosto, é a acusação de estrupo levantada contra Neymar da Silva Santos Júnior por Najila Trindade Mendes de Souza. As matérias sobre essa acusação acabam por configurar nosso principal termômetro quanto ao teor dos discursos circulantes, aos focos de imaginários sociodiscursivos e ao ideal de respeito aos direitos humanos que orienta nossa cultura.

Em primeiro lugar, tais matérias procuram uma linguagem e composição isenta, atendo-se aos fatos com fidelidade e tratando a acusadora com a neutralidade do termo "suposta vítima". No entanto, é de se notar que, desde a primeira notícia divulgada, em 10 de junho, o jornal dá voz a Neymar, a seus advogados e a seu pai, cujas afirmações ocupam destacado espaço nas matérias. Efeito da notoriedade do acusado ou a suposta vítima já foi posta de lado?

Com certeza testemunhamos um efeito de poder quando um jornalista é desligado de suas funções na Globo por ter fornecido número de celular do pai de Neymar ao advogado da suposta vítima. As subsequentes reportagens frisam o fato de que o encontro entre Najila e Neymar se deu em 15 de maio e ela só registrou sua queixa em $1^{0}$ de junho, ênfase que coloca de antemão uma discrepância a agravar situação de Najila, como se a acusação fosse "coisa de caso pensado".

Agora, em termos de filiação, seja ela por gênero, por profissão ou por partilha de um imaginário sociodiscursivo em que a mulher nunca é vítima, pois é 
de antemão a culpada de algum plano maquiavélico, temos um exemplo na matéria de 2 de junho, dia seguinte à acusação, cuja manchete tudo diz: "Jogadores da seleção defendem Neymar após acusação de estupro". Certamente os defensores, antes que os fatos se demonstrem ou se verifiquem, concebem a relação entre homem e mulher como situação pautada pela sedução com o intuito de tirar proveito. Devem entender, nessas condições, que os homens estão sempre isentos de culpa, presas fáceis que são, e Neymar só pode ser inocente.

Assim, se as matérias tentam narrar as ocorrências com imparcialidade, entretanto deixam escapar esses sinais de um jogo de antigos estereótipos que são reiterados nos modos de contar assim como nas ações dos envolvidos nesse primeiro estágio em que ainda nada foi devidamente confirmado. Fora dessas reportagens no jornal, cria-se um clima de buchicho, nos comentários de leitores e nas redes sociais, que motivaram Contardo Calligaris a escrever, em sua coluna, "Najila, Neymar e os comentários. Muitos nem cogitam a possibilidade de que as mulheres tenham desejos sexuais".

Não sabemos qual das versões será comprovada pela Justiça, se uma puder ser. Tanto faz, esta coluna não é sobre o encontro de Najila e Neymar, mas sobre as coortes de homens que declararam seu apoio ao jogador: os que estiveram se manifestando na frente da delegacia durante o depoimento dele, os que se expressaram por Neymar e contra Najila online e os inúmeros que absolveram Neymar e condenaram raivosamente Najila, conversando nos bares e botecos.

A maioria desses comentários masculinos obedecia a uma mesma lógica: a mina vai até Paris com a passagem paga pelo cara e acha o quê? Na última hora ela diz que não quer? Ajoelhou, tem que rezar. É a mesma estupidez pela qual mulher de minissaia, se for estuprada, é porque queria mesmo.

É óbvio que qualquer um pode levantar no meio da reza e decidir que já rezou o suficiente. "Não é não" em qualquer momento. Mike Tyson forçou a barra com uma mulher que foi até seu quarto de hotel e disse não: ele passou três anos na cadeia.

Apesar dessa obviedade, dos botecos ao Palácio da Alvorada, há homens dispostos a desculpar Neymar desde já. O que os anima? A resposta é simples: o ódio pela mulher que está no centro e na base da cultura ocidental, sobretudo cristã. 
Desde a história de Adão e Eva no paraíso terrestre, o mal vem ao mundo pela mulher tentadora. É com ela que a serpente conversa, e juntas elas tramam a perdição do homem. Se é que Neymar fez algo errado, ele não tem culpa, porque foi "tentado". Coitadinho.

É tentando o homem que a mulher arma ciladas. É isso que as mulheres fazem, aliás: elas armam ciladas.

Os que evocam os enganos da "ardilosa" Najila, de fato, nem sequer cogitam a possibilidade de que as mulheres tenham desejos sexuais, tanto quanto os homens. Para eles, as mulheres apenas tentam os homens (os quais acabam assim desejando, mas sem que seja "culpa" deles). Ou seja, as mulheres não querem transar, nunca; o que elas querem é enredar os homens em cada tipo de armadilha: por exemplo, querem engravidar e ganhar pensão para o resto da vida.

Najila, para esses acusadores, é insuportável, pois, desde seu primeiro depoimento, ela declara sem hesitar que foi a Paris para transar com Neymar. Onde já se viu? Uma mulher a fim de transar? Cuidado, deve ser uma cilada". (CALLIGARIS, 2019)

E assim, Calligaris nos oferece o desenho de um imaginário sociodiscursivo que persiste, reverbera e insiste. Talvez possamos adensar essa representação do macho sempre isento, ou até mesmo do estupro como prerrogativa, recorrendo ao outro fato notório do mês de junho relatado na matéria do dia 13 deste mês "Por ordem judicial, Bolsonaro pede desculpas à deputada Maria do Rosário. Presidente foi obrigado a postar mensagem por ter dito que petista 'não merecia ser estuprada'".

Nos demais meses temos desdobramentos de casos antigos, reverberações a partir do movimento MeToo, várias acusações e condenações. Uma matéria de agosto capta nossa atenção e incide sobre essa ideia do estrupo como prerrogativa ou ação masculina de direito, com circunstâncias que o isentam. Em 8/8/2019, temos "Tribunal absolve acusado de estupro com alegação que vítima estava bêbada. Duas juízas e um juiz decidiram, por unanimidade, inocentar o homem em segunda instância". É assustadora a conclusão jurídica relatada na matéria, tanto mais por comportar duas juízas que, ignorando todas as provas, respaldaram o acusado:

Em julho deste ano, três juízes - entre eles duas mulheres - da $5^{a}$ Câmara Criminal do Tribunal de Justiça do Rio Grande do Sul (TJ) entenderam que ele era inocente e o absolveram por unanimidade. 
Cristina Pereira Gonzales, a relatora, João Batista Marques Tovo e Lizete Andreis decidiram que, apesar das provas, se a garota "bebeu por conta própria, dentro de seu livre arbítrio, não pode ela ser colocada na posição de vítima de abuso sexual pelo simples fato de ter bebido". (SPERB, 2019)

Constatamos, com a captação dessa fase da ação judicial, e em relação a nossa cultura, a preservação de tradicionais representações do masculino e do feminino, com os papéis sociais e os estereótipos que lhes são atribuídos. Mais que isso, notamos a adesão das mulheres a preconceitos contra as próprias mulheres afinal, mulher decente não bebe -, na forma como as juízas se manifestaram, desconsiderando provas bastante explícitas. No entanto, é preciso enfatizar que a própria matéria jornalística denota desconforto e descontentamento com os termos do julgamento.

\section{Ações em prol das mulheres, embates, manifestações públicas}

Na sequência das maiores incidências estão arroladas as notícias dessa temática/categoria. Concentradas nos meses de março e maio, elas obedecem a certo calendário de efemérides. Março, com o Dia Internacional das Mulheres, é o momento do ano em que todos, jornais, políticas públicas e políticos, estão preocupados em mostrar comprometimento com ações que beneficiem as mulheres em todos os setores sociais e, sobretudo, com ações que as protejam das variadas formas de abuso a que são submetidas. Assim, surgem expressões públicas de personagens com notoriedade e de grupos engajados em reivindicações para as mulheres.

É sob essa rubrica que vemos com clareza dois Brasis explicitamente declarados. Invocamos duas matérias de 8/3/2019. Numa, "Bolsonaro diz que cada uma das duas ministras vale por dez homens Em discurso no Dia da Mulher, presidente cita Bíblia e afirma que 'mulher sábia edifica o lar'", temos estampada uma visão tradicional e estereotípica das mulheres como seres "do lar". É importante lembrar que, em outras declarações, o presidente, assim como vários de seu grupo político, reitera uma compreensão das mulheres que ignora muitos dos direitos humanos que nos orientam hoje em dia. 
Ainda em 8/3/2019, outra matéria - "Marcha das mulheres em SP é marcada por críticas a Bolsonaro e homenagens a Marielle" - mostra o contraponto no ativismo feminino que condena ações do governo Bolsonaro enquanto reivindica justeza para as mulheres. A tão comentada polarização que nos acometeu nos últimos tempos se vê representada nos dois momentos acima mencionados.

Em 7/5/2019, destacamos a matéria "Ministério da Saúde veta uso do termo 'violência obstétrica'" para mostrar que sob essa rubrica estão matérias com manifestações públicas, como decisões institucionais, que afetam de algum modo o universo feminino. No geral, são matérias carregam um forte teor de positividade, mostrando elogiosamente ações consideradas afirmativas. É marcante o sancionamento de leis, portarias etc. a favor das mulheres, como a relatada pela matéria de 3/7/2019, "Comissão do Senado aprova inclusão de prevenção à violência contra mulher nas escolas".

O mês de julho justifica o tom de quase euforia diante de medidas positivas, pois, afinal, em 7/7/2019 uma matéria anuncia: "Câmara vê explosão de projetos para combater violência contra mulheres". No subtítulo temos uma indicação comparativa: "Em 5 meses, atual legislatura soma ao menos 145 iniciativas; anterior propôs 50 no primeiro ano".

Isolamos matéria de agosto (8/8/2019) por mostrar as mazelas de muitas ações em prol das mulheres, pois denota que leis esbarram em velhos preconceitos que vivem continuadamente em nossa cultura: "Lei Maria da Penha deu frutos, mas falta sensibilizar juízes, mostra estudo do $\mathrm{CNJ}^{\prime \prime}$. Há referências a providências internacionais em prol das mulheres. Para mostrar que o jornal não se restringe às reverberações do movimento MeToo, trazemos matéria desse teor, veiculada em 10/8/2019. Ela mostra medidas de enfrentamento aos tão comentados casos de estrupo coletivo na Índia: "Passe livre a mulheres como medida para evitar estupros gera polêmica na Índia".

Na continuidade das notícias sob a categoria Ações em prol das mulheres, temos, ao longo do ano e sobretudo nos últimos meses de 2019, relatos sobre o desdobramento das ações, seus interstícios e suas resoluções. Em $1^{\circ}$ de 
novembro, observamos a notícia de que "Grupo antiaborto acampa diante de hospital em SP para constranger vítimas de estupro", num movimento reverso em relação à autonomia feminina.

De março de 2020, quando o primeiro ano da coleta se encerra, queremos destacar quatro matérias, cada uma delas com a peculiaridade de desenhar discursos que circulam em nossa cultura. Em 7 de março, com "Mulheres de direita veem 8 de março sequestrado pela esquerda e celebram com ações próprias", o jornalismo anota segmento populacional que faz protesto com outros tons por não aderir a vários dos ativismos que costumam marcar presença no calendário oficial de comemorações. No mesmo dia, a matéria "'Manifestações do Dia da Mulher' ganham tom de resposta a ato pró-Bolsonaro" mostra bem a dimensão política que, extrapolando o âmbito feminino, se engata nos enfrentamentos e aproveita a ocasião para posicionar-se contra Bolsonaro, ou contra aqueles que saem em apoio ao presidente.

Como de hábito, alguma matéria deve mostrar, no Dia Internacional da Mulher, a bravura das mulheres em meio a condições desfavoráveis, à fragilidade que Ihes é imposta por uma cultura que tem compactuado com a violência a que são submetidas: "Mulher, como inúmeras brasileiras. Marielles sobrevivem, apesar de violências e assédios". A perspectiva internacional também é mostrada e comparece com a matéria, em 8 de março, "Mulheres turbinam protestos com dois dias de ato e greve na América Latina". Quero anotar aqui que, na América Latina e mundo afora, onde foi possível manifestar-se, o Dia Internacional da Mulher foi marcado pelos manifestos em oposição a governantes do momento.

\section{Condição feminina: panorama, ponderações}

Essa categoria ocupa a próxima posição em termos de porcentagens. As matérias sob essa rubrica acontecem com mais frequência nos meses de março, junho e agosto, com presença irrelevante nos demais meses. Muitas vezes mostra a real condição feminina ao relatar evento paradoxal, por exemplo, a comemoração do Dia Internacional da Mulher em ambiente totalmente masculino, em 8/3/2019 "Com apenas presidentes homens, Bolsa promove evento sobre gênero". 
Sob essa categoria estão arroladas diversas reflexões sobre a condição feminina. Na matéria acima, podemos considerar que o jornal avalia tal condição, trazendo um caso que rompe com certo silêncio e a revela. Contudo, as reflexões mais importantes são trazidas na esteira de entrevistas, como a matéria de 8/3/2019, "Futuro do feminismo depende de reinvenção de masculinidade, afirma autora" em que Olívia Gazalé (2017) fala sobre seu livro (O mito da virilidade) explicando suas ideias sobre a identidade masculina, ontem e hoje. Igual situação é encontrada na da matéria de 6/5/2019, "Homofobia de hoje é resultado direto dos erros da esquerda, diz Camille Paglia", que traz entrevista com famosa e polêmica professora universitária, anti movimento feminista e ativista transgênero.

Algumas notícias trazem informações que nos levam a constatar a primazia do referencial masculino, como em 9/3/2019, "Obra aponta dano a mulheres gerados por dados enviesados". A matéria trata de pesquisas para produção de remédios que não fazem testes com mulheres, desconsiderando diferenças fisiológicas que podem levar a outros achados: surpreendente!

Sempre lembradas em data próxima ao Dia Internacional da Mulher estão as ponderações delineadas por Simone de Beauvoir, como um marco histórico. Em 10/3/2019, temos: "Após 70 anos, Simone de Beauvoir ainda mostra caminho da liberdade feminina".

Os modos no tratamento da condição feminina constituem outro fato que nos mostra a persistência dos preconceitos e do desrespeito. Por exemplo, em 30/5/2019, é reveladora a matéria "Juiz eleitoral compara mulheres que preenchem cota em eleição a 'aleijados'". Será que ele aplicaria essa terminologia a homens?

Por outro lado, em 6/6/2019, "Proibido no Brasil, futebol feminino já foi até atração de circo", temos referência ao passado da condição feminina que assume um viés anedótico, quando mostrada pela ótica de nossos dias. Novamente, algumas reflexões fazem emergir a consolidação de papéis femininos socialmente validados, os estereótipos que os determinam, em prejuízo de uma gama de representações sociais possíveis. Por exemplo, em 18/6/2019 temos, ainda que 
contestatória, uma interrogação que confirma uma situação: "Por que as mulheres, e não os homens, são julgadas pela casa bagunçada".

É relevante para nossas considerações o fato relatado em matéria de 10 de agosto "Famosas abusadas têm o benefício da dúvida, as imigrantes não, diz finalista do Pulitzer". Trata-se de mostrar a discriminação por raça ou segmento social, por nós anteriormente apontada, que coloca as mulheres desses cenários em condições ainda mais precárias, pois invisíveis aos olhos da justiça e das mídias. Uma vez mais o que está posto em livros serve de baliza para pensar a violência contra as mulheres, como na matéria de 10/8/2019, "Estupro na literatura pode reforçar intimidação da mulher, diz escritora".

Apesar das notações e alusões à fragilidade das mulheres em nossa cultura, há um quadro social, ao menos em declarações, a favor do respeito às mulheres. A matéria de 23 de outubro, "Paulistanos defendem lei dura e direitos de mulheres e negros, diz pesquisa" apresenta um panorama que aponta para transformações culturais em benefício das mulheres.

No mesmo registro encontram-se as matérias em 9/12/2019, "Estupro: um custo intolerável à sociedade, em 29/12/2019, e "Debate sobre armas ignora feminicídios". Ambas alertam para situações de violência contra as mulheres, de forma bastante reivindicatória. A realidade das condições, melhor dizendo, das limitações e desrespeitos, nos confronta na matéria de 7 de fevereiro de 2020, "Assédio, estrutura precária e insegurança afastam mulheres de estádios".

E a matéria em 8/3/2020, "Repudiar Polanski não é 'cancelar', mas dar um basta à cultura da hipocrisia", muda o foco das discordâncias sobre o recebimento de prêmios por alguém considerado desrespeitador dos direitos das mulheres. Trata-se de anular toda forma de silenciamento, de acobertamento da infração, tal como honras concedidas a acusados de violência contra as mulheres.

\section{Dados/porcentagens}

Por último estão as notícias que tratam dos abusos contra as mulheres e os descrevem em termos de levantamentos e contabilização. A categoria 
Dados/porcentagens funciona como um desenho da real situação pois traz os resultados dos mais recentes levantamentos em relação à violência contra as mulheres. O conjunto comporta maior incidência em março, abril e setembro. Em março, as matérias que trazem tais informações emergem, na maioria das vezes, em virtude do Dia Internacional da Mulher. A matéria de 8/3/2019, "71\% dos feminicídios e das tentativas têm parceiro como suspeito", traz histórias de perseguição e assassinato junto com amplas informações sobre a situação resultante de pesquisas. Anuncia que:

Levantamento feito pela Folha para marcar o Dia Internacional da Mulher, celebrado nesta sexta (8), mostra que $71 \%$ dessas mulheres [...] As estatísticas foram compiladas pela Folha a partir de um levantamento ${ }^{4}$ feito pelo advogado Jefferson Nascimento, pesquisador da USP, que se baseia em casos publicados na imprensa brasileira. A Folha analisou notícias e tabulou dados disponíveis sobre cada caso. São 119 mortes e 60 tentativas de feminicídio. A análise, que abrange crimes ocorridos em 25 estados, mostra que a mulher vitimada pelo crime tem, em média, 33 anos, e o agressor, um pouco mais: 38 anos. O inconformismo com o fim do relacionamento aparece entre os motivos mais citados para a agressão (18\%), logo atrás de brigas, ciúmes ou suposta traição (25\%). [...] Dos casos analisados pela Folha, pelo menos 11 culminaram no suicídio do agressor. Em 15 deles, crianças presenciaram o crime. [...] No levantamento da Folha, $47 \%$ dos crimes ocorreram na casa da vítima. A faca foi a arma mais usada (41\%), seguida por armas de fogo (23\%). Nos casos estudados, $74 \%$ dos crimes cometidos com armas de fogo resultaram em morte -contra $59 \%$ no caso de agressões a facadas. (CARAZZAI et al., 2019)

No total, os crimes em janeiro de 2019 perfazem 179 casos, dos quais em 119 casos a mulher morreu e em 60 a mulher sobreviveu. O local da agressão é a casa da vítima em $47 \%$ dos casos, a rua em $20 \%$ dos casos. Dos tipos de armas usadas, destaca-se arma branca em $41 \%$ dos casos, arma de fogo em $23 \%$, espancamento em $15 \%$ e asfixia em $9 \%$. Resumimos os dados para oferecer aqui um quadro da situação em março de 2019. Mas, não podemos deixar de 
acrescentar um outro dado trazido pela matéria de 23/3/2019, "Registros de crimes sexuais em coletivos de SP crescem 265\% em 11 anos".

De abril é preciso enfatizar um dado a que já referenciamos anteriormente, a saber, o olhar feminino preconceituoso em relação às próprias mulheres (matéria sobre julgamento de estrupo no Rio Grande do Sul), que vem à tona na matéria de 14/4/2019, "Feminismo é mais bem avaliado entre homens que entre mulheres, diz Datafolha".

Também destacamos o início de uma avalanche de casos específicos de violência contra as mulheres marcada pela matéria de 5/6/2019, "Morte de mulheres dentro de casa cresce $17 \%$ em cinco anos". Ao lado disso, a matéria de 9 de setembro marca uma progressão, "Brasil registra 1 caso de agressão a mulher a cada 4 minutos, mostra levantamento", reconfirmada por matéria de 26 de outubro, "Registros de estupro em SP têm $2^{\circ}$ pior mês desde 2010".

Em 7 de novembro, a matéria "Educação para a equidade de gênero não é ideologia, mas questão de direitos humanos, diz juiz" levanta explicitamente a questão da violência doméstica que vinha assomando, timidamente, aqui e acolá, mas nesse momento foi posta como situação premente. O dia 4 de dezembro nos brinda com mais um dado da violência contra mulheres: "A cada 20 minutos, 1 menina é vítima de estupro no país. Levantamento do Fórum Brasileiro de Segurança Pública mostra que houve 50.899 registros de crimes contra jovens de até 18 anos em 2017 e 2018". O dia 22 de fevereiro de 2020 sela tema que absorve toda a nossa atenção: "Feminicídio cresce no Brasil explode em alguns estados. Compilação inédita de dados mostra registro de 1.310 mulheres mortas por violência doméstica em 2019"5.

\section{Breve arremate}

Ao longo das matérias destacadas por serem mais representativas dos vieses assumidos nas narrativas dos fatos que colhemos junto à Folha de S.Paulo, estivemos passo a passo analisando e comentando os pontos indicativos da 
percepção do jornal e de nossa cultura sobre a violência contra as mulheres em suas variadas formas. No geral, detectamos um quadro de empenho, na sociedade, pela formulação de leis, dispositivos de apoio a vítimas, facilitação de denúncias, penalidades a infratores etc. Tudo indica que esse quadro é ponto consolidado nos discursos que circulam em nossa cultura e leva, efetivamente, a alguma proteção das mulheres no que tange a violência.

Naturalmente, faz parte desse quadro o próprio jornal em que as localizamos, já que houve escolha, posicionamento a favor, dimensionado pela opção de divulgação. Por outro lado, há matérias que apontam para uma realidade que parece desdizer o panorama favorável. No que trouxemos até agora, podemos bem ver as palavras de Olivia Gonzalé, aliás uma das entrevistadas pelo jornal: "Hoje em dia, a violação é severamente punida; no entanto, esse retorno da culpabilidade, que transforma a vítima em culpada, permanece uma constante" (tradução nossa) ${ }^{6}$.

Vimos essa situação de modo enviesado, nos relatos sob a categoria Casos, na referência à comprovada vítima que foi responsabilizada pelo ato do infrator (infrator absolvido), nas manifestações de apoio a acusado de violência, antes que qualquer prova, pelo sim ou pelo não, tivesse sido examinada. Contudo, de todo o nosso trajeto, o que talvez marque um discurso que circula em nossa cultura, na contramão das ações e discursos pelo respeito e pelos direitos das mulheres, seja a declaração que coloca o estrupo como um "dom" a ser concedido somente a algumas mulheres, aquelas que o merecem.

É muito difícil afirmar, a partir de nosso estudo, o que seria prevalente em nossa cultura: as ações em prol do respeito às mulheres ou os abusos, a circulação de discursos por equidade ou a preservação de imaginários sociodiscursivos que as mantém como indivíduos a serem, legitimamente, submetidos a abusos. No entanto, podemos afirmar com segurança que as duas posições se fazem presentes em nossos dias. Aliás, a julgar pelas notícias do final de 2019 e começo de 2020 , é certo que os abusos, em certo contorno, tiveram substancial aumento. 
Desde o fim de 2019, e fortemente assinalada no começo de 2020, mescla-se às matérias levantadas com nossas palavras chaves, um tipo específico de violência: a violência doméstica. Quanto a isso, recuperamos matéria de 22/2/2020, que nos diz: "Feminicídio cresce no Brasil e explode em alguns estados. Compilação inédita de dados mostra registro de 1.310 mulheres mortas por violência doméstica em 2019". Com esse dado em mente, que nos levou a uma mudança de rumos, encerramos o presente trajeto anunciando um foco preciso para a próxima etapa de pesquisa, a saber, violência doméstica como nova e central palavra chave.

\section{Referências}

BOURDIEU, P. Sobre a televisão: a influência do jornalismo e os Jogos Olímpicos. Rio de Janeiro: Jorge Zahar, 1997.

CALLIGARIS, C. Najila, Neymar e os comentários: muitos nem cogitam a possibilidade de que as mulheres tenham desejos sexuais. Folha de S.Paulo, São Paulo, 20 jun. 2019. Disponível em: https://www1.folha.uol.com.br/colunas/ contardocalligaris/2019/06/najila-neymar-e-os-comentarios.shtml. Acesso em: 28 jun. 2021.

CARAZZAI, E. H. et al. 71\% dos feminicídios e das tentativas têm parceiro como suspeito. Folha de S.Paulo, São Paulo, 8 mar. 2019. Disponível em: https://www1. folha.uol.com.br/cotidiano/2019/03/71-dos-feminicidios-e-das-tentativas-temparceiro-como-suspeito.shtml. Acesso em: 28. jun. 2021.

CHARAUDEAU, P. Discurso das mídias. São Paulo: Contexto, 2006.

CHARAUDEAU, P. Discurso político. São Paulo: Contexto, 2008. 
DUCROT, O. Princípios de linguística semântica: dizer e não dizer. São Paulo: Cultrix, 1977.

FOUCAULT, M. A ordem do discurso. São Paulo: Loyola, 1996.

FOUCAULT, M. As palavras e as coisas. São Paulo: Martins Fontes, 1995.

GAZALÉ, O. Le mythe de la virilité. Un piège pour les deux sexes. Paris: Éditions Robert Laffont, 2017.

HALL, S. A identidade cultural na pós-modernidade. Rio de Janeiro: DP\&A, 2000.

Instituto de Pesquisa Econômica Aplicada; FÓRUM BRASILEIRO DE SEGURANÇA PÚBLICA. Atlas da violência 2017. Brasília, DF: Ipea; Fórum Brasileiro de Segurança Pública, 2017. Disponível em: http://www.ipea.gov.br/portal/images/170609_ atlas_da_violencia_2017.pdf. Acesso em: 20 maio 2018.

MAINGUENEAU, D. Novas tendências em análise do discurso. Campinas: Pontes, 1993.

MAINGueneAU, D. Gênese dos discursos. São Paulo: Parábola Editorial, 2008.

ORLANDI, E. As formas do silêncio: no movimento dos sentidos. Campinas: Editora da Unicamp, 2007.

SPERB, P. Tribunal absolve acusado de estupro com alegação que vítima estava bêbada. Folha de S.Paulo, Porto Alegre, 8 ago. 2019. Disponível em: https://www1. folha.uol.com.br/cotidiano/2019/08/condenado-a-dez-anos-de-prisao-por-estupromotorista-e-absolvido-apos-recorrer.shtml. Acesso em: 28 jun. 2021. 